\title{
Biobased additive plasticizing Polylactic acid (PLA)
}

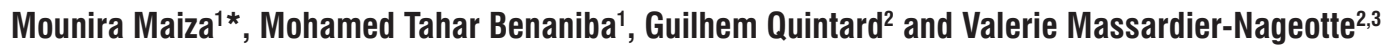

\author{
${ }^{1}$ Laboratoire des Matériaux Polymériques MultiPhasiques, Faculté de Technologie, \\ Université Ferhat ABBAS, Sétif, Algérie \\ 2INSA-Lyon, Ingénierie des Matériaux Polymères - IMP, Villeurbanne, France \\ ${ }^{3}$ Université de Lyon, Lyon, France \\ *mounira1990@live.com
}

\begin{abstract}
Polylactic acid (PLA) is an attractive candidate for replacing petrochemical polymers because it is from renewable resources. In this study, a specific PLA 2002D was melt-mixed with two plasticizers: triethyl citrate (TEC) and acetyl tributyl citrate (ATBC). The plasticized PLA with various concentrations were analyzed by differential scanning calorimetry (DSC), dynamic mechanical analysis (DMA), melt flow index (MFI), thermogravimetric analysis (TGA), X-ray diffraction (XRD), UV-Visible spectroscopy and plasticizer migration test. Differential scanning calorimetry demonstrated that the addition of TEC and ATBC resulted in a decrease in glass transition temperature $\left(\mathrm{T}_{\mathrm{g}}\right)$, and the reduction was the largest with the plasticizer having the lowest molecular weight (TEC). Plasticizing effect was also shown by decrease in the dynamic storage modulus and viscosity of plasticized mixtures compared to the treated PLA. The TGA results indicated that ATBC and TEC promoted a decrease in thermal stability of the PLA. The X-ray diffraction showed that the PLA have not polymorphic crystalline transition. Analysis by UV-Visible spectroscopy showed that the two plasticizers: ATBC and TEC have no effect on the color change of the films. The weight loss plasticizer with heating time and at $100^{\circ} \mathrm{C}$ is lesser than at $135^{\circ} \mathrm{C}$. Migration of TEC and ATBC results in cracks and changed color of material. We have concluded that the higher molecular weight of citrate in the studied exhibited a greater plasticizing effect to the PLA.
\end{abstract}

Keywords: Polylactic acid (PLA), plasticizer, triethyl citrate, acetyl tributyl citrate.

\section{Introduction}

Biobased polyesters have attracted much attention due to their biodegradability and biocompatibility which offer clear advantages for both customers and environment. In recent years, Polylactic acid (PLA) is one of the most promising candidates as partial alternative of petrochemical polymers because it is biodegradable and produced from lactic acid obtained by fermentation of renewable raw materials and readily biodegradable ${ }^{[1]}$. PLA like most synthetic polymers from petroleum resources, which are rarely used alone by themselves, and needs to improve some properties by an inclusion of additives ${ }^{[2]}$.

Poly (lactic acid) PLA has very low toxicity and high mechanical performance, comparable to other commercial polymers, for example, poly (ethylene terephthalate) (PET) and polystyrene (PS) ${ }^{[3-5]}$. It is highly transparent and has good barrier properties to aromas. In addition, PLA is also biodegradable, compostable and has good mechanical properties ${ }^{[5,6]}$. However, its major drawbacks as high cost and intrinsic characteristics (i.e. hard and brittle materials) have hindered its wide spread use, especially in the area of packaging applications ${ }^{[7-9]}$. Plasticizers are widely used additives for polymeric materials to enhance their flexibility, processability, and ductility. Generally, an efficient plasticizer has to reduce the glass transition temperature $\left(T_{g}\right)$ and melting point of the plasticized materials ${ }^{[10]}$. Different types of plasticizers have been investigated to improve the flexible properties of PLA such as poly (ethylene glycol) (PEG), citrate esters $^{[11-15]}$, oligomeric lactic acid ${ }^{[16]}$ and triacetine ${ }^{[14,16]}$. There are several important considerations when choosing a plasticizer for PLA for biomedical applications. It should be a nontoxic substance miscible with the polymer, thus creating a homogeneous blend. Also, the plasticizer should not be prone to migration as this would cause the material to regain the brittleness of pure PLA ${ }^{[17]}$. Thus, good miscibility between PLA and plasticizers is essential. Various plasticizers, which have been proved as effective plasticizers for PLA, citrate esters are used as plasticizers with a variety of different polymers such as poly (methyl methacrylate) ${ }^{[18]}$ and cellulose acetate ${ }^{[19]}$. They are nontoxic and approved for use as additives in food, personal care products, and in medical plastics ${ }^{[18]}$. The reason for good solubility of citrate plasticizers in PLA is due to the polar interactions between the ester groups of PLA and the plasticizer ${ }^{[20]}$.

Two biodegradable, nontoxic plasticizers that have been successfully blended with PLA are triethyl citrate (TEC) and acetyl tributyl citrate (ATBC). At the concentrations used (up to $30 \%$ ) these esters were shown to be compatible with PLA and to generate significant decrease in glass transition temperature, thereby enhancing the ductility of the material. The aim of this study is to investigate the effects of TEC and ATBC with various molecular weight and contents on thermal, dynamical, rheological and plasticizer migration properties of PLA. 


\section{Materials and Methods}

\subsection{Materials}

Poly (lactic acid) (PLA 2002D, extrusion grade, MFI: $5-7 \mathrm{~g} 10 \mathrm{~min}$ at $210{ }^{\circ} \mathrm{C}, 2.16 \mathrm{Kg}$ ) was provided by Cargill-Dow (USA). The melting temperature $\left(\mathrm{T}_{\mathrm{m}}\right)$ was $180^{\circ} \mathrm{C}$ and the glass transition temperature $\left(\mathrm{T}_{\mathrm{g}}\right)$ was $60^{\circ} \mathrm{C}$, acetyl tributyl citrate (ATBC) and triethyl citrate (TEC) (Scheme 1a and 1b) were purchased from Sigma Aldrich (France).

\subsection{Sample preparation}

Before processing by melt-blending PLA was dried for $24 \mathrm{~h}$ at $60{ }^{\circ} \mathrm{C}$, PLA was blended with the plasticizers in a Brabender plastograph. The temperature was $190{ }^{\circ} \mathrm{C}$ and the blending time $7 \mathrm{~min}$, and blend rotation speed was $30 \mathrm{rpm}$. The plasticizers TEC and ATBC were blended to PLA at 5, 10, 15, 20 and 30\% weight. Table 1 summarizes the compositions of each formulation.

\subsection{Characterization}

\subsubsection{Differential scanning calorimetry (DSC)}

Differential scanning calorimetry (DSC) was conducted on a TA instruments DSC Q10. All samples were exposed to consecutive heating and cooling programs to eliminate their thermal history: first heating from $25^{\circ} \mathrm{C}$ to $220^{\circ} \mathrm{C}$, isothermal for $3 \mathrm{~min}$, cooling from $220^{\circ} \mathrm{C}$ to $-50{ }^{\circ} \mathrm{C}$, isothermal for $3 \mathrm{~min}$, and second heating from $-50^{\circ} \mathrm{C}$ to $220^{\circ} \mathrm{C}$. The heating and cooling rates were $10{ }^{\circ} \mathrm{C} \mathrm{min}^{-1}$.<smiles>CCOC(=O)CC(O)(CCOC(C)=O)C(=O)OCC</smiles>
(TEC) $\left(\mathrm{M}_{\mathrm{w}}=276.28 \mathrm{~g} \cdot \mathrm{mol}^{-1}\right)$

(a)<smiles>CCCCOC(=O)CC(CC(=O)OCCCC)(OC(C)=O)C(=O)OCCCC</smiles>

(ATBC) $\left(\mathrm{M}_{\mathrm{w}}=402.48 \mathrm{~g} \cdot \mathrm{mol}^{-1}\right)$

(b)

Scheme 1. Chemical structure of: (a) (TEC); (b) (ATBC).

\subsubsection{Dynamic mechanical analysis (DMA)}

Measurements were carried out with a dynamic mechanical analyzer (RSAII) at a frequency of $1 \mathrm{~Hz}$. All films $\left(30 \times 7 \times 0.5 \mathrm{~mm}^{3}\right)$ were tested at a strain of $0.01 \%$ using a $3{ }^{\circ} \mathrm{C} \mathrm{min}{ }^{-1}$, temperature ramp from -50 to $120{ }^{\circ} \mathrm{C}$.

\subsubsection{Melt flow index (MFI)}

Melt flow index (MFI) is the mass flow rate index, expressed in grams, extruded isothermally 10 min under constant load through a die of standard dimensions was measured by using Melt Flow Indexer (MFI Controlab Melt flow rate apparatas model 5) at $190{ }^{\circ} \mathrm{C}$ and $2.16 \mathrm{Kg}$.

\subsubsection{Thermogravimetric analysis (TGA)}

Thermogravimetric analysis (TGA) of the samples was studied by using TA instrument Q100 (TA). The samples were heated from 30 to $500{ }^{\circ} \mathrm{C}$ with the heating rate of $10{ }^{\circ} \mathrm{C} \mathrm{min}^{-1}$ under nitrogen atmosphere at the flow rate of

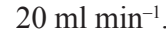

\subsubsection{X-ray diffraction (XRD)}

X-ray diffraction (XRD) of films study was carried out using a Bruker D8 Advance diffractometer with $\mathrm{Cu}-\mathrm{Ni}$ radiation $(\lambda=1.54184 \mathrm{~nm})$. The diffractogram was scanned in the ranges from $6-70^{\circ}$ at a scan rate of $0.05^{\circ} \mathrm{min}^{-1}$.

\subsubsection{UV-Visible spectroscopy}

The light transmittance of treated and plasticized PLA with TEC and ATBC were measured with a UV-Visible spectrophotometer instrument (Unicam 300UV; England) in the range of 200-600 $\mathrm{nm}$ at room temperature.

\subsubsection{Plasticizer migration}

The samples were placed in a vented oven at isothermal temperatures of 100 and $135^{\circ} \mathrm{C}$. In defined time intervals $(200,400,600$ and $800 \mathrm{~min})$ the samples were weighted. Before weighting the surface were cleaned up from the migrated plasticizer ${ }^{[2]}$. The weight loss of the plasticizer was assumed as the total weight loss of the samples during heating time $(\mathrm{t})$ and calculated according to Equation 1:

$$
\text { Weight } \operatorname{loss}(\%)=\frac{\mathrm{m}_{0}-\mathrm{m}_{\mathrm{t}}}{\mathrm{m}_{0}} \times 100
$$

where $m_{0}$ is the weight before migration and $m_{t}$ is the weight of after migration at $t$.

Table 1. Composition of treated (Trt) PLA and plasticized PLA with TEC and ATBC plasticizers.

\begin{tabular}{ccc}
\hline Formulation & PLA (\%) & TEC or ATBC (\%) \\
\hline Trt PLA & 100 & 0 \\
PLA-TEC5 & 95 & 5 \\
PLA-TEC10 & 90 & 10 \\
PLA-TEC15 & 85 & 15 \\
PLA-TEC20 & 80 & 20 \\
PLA-TEC30 & 70 & 30 \\
PLA-ATBC5 & 95 & 5 \\
PLA-ATBC10 & 90 & 10 \\
PLA-ATBC15 & 85 & 15 \\
PLA-ATBC20 & 80 & 20 \\
PLA-ATBC30 & 70 & 30 \\
\hline
\end{tabular}




\section{Results and Discussion}

\subsection{Differential scanning calorimetry (DSC)}

During the last heating scan the glass transition, cold crystallization and melting temperature of the material were determined. The degree of crystallinity $\left(\mathrm{X}_{c}\right)$ was calculated from the DSC data using the following relationship:

$$
\mathrm{X}_{\mathrm{c}}(\%)=\frac{\Delta \mathrm{H}_{\mathrm{m}}-\Delta \mathrm{H}_{\mathrm{cc}}}{\Delta \mathrm{H}_{\mathrm{f}} \Delta \mathrm{X}_{\mathrm{PLA}}} \times 100
$$

where $\Delta \mathrm{H}_{\mathrm{m}}, \Delta \mathrm{H}_{\mathrm{cc}}$ and $\mathrm{X}_{\mathrm{PLA}}$ are the enthalpy of melting, enthalpy of cold crystallization and weight fraction of PLA respectively, $\Delta \mathrm{H}_{\mathrm{f}}$ is the heat of fusion defined as the melting

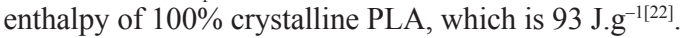

The differential scanning calorimetry (DSC) results (last scan) for the treated and plasticized PLA in Brabender plastograph are shown in Figure 1 and summarized in Table 2.
The plasticizers decreased the glass transition temperature ( $\mathrm{T}_{\mathrm{g}}$ ) of treated PLA from $60.42^{\circ} \mathrm{C}$ to $10.29^{\circ} \mathrm{C}$ and to $12.21^{\circ} \mathrm{C}$ with addition $30 \%$ of TEC and ATBC respectively. As expected, by increasing plasticizer content, a decrease in $\mathrm{T}_{\mathrm{g}}$ occurs, which is true for the TEC and ATBC. The low molecular size of the plasticizer allows it to occupy intermolecular spaces between polymer chains, reducing the energy for molecular motion and the formation of hydrogen bonding between the polymer chains, which in turn increases free volume and molecular mobility. By increasing the content of the plasticizer, the effectiveness of the citrate plasticizer to reduce the $T_{g}$ of the PLA is generally enhanced ${ }^{[20]}$.

The addition of TEC or ATBC to the PLA affects the cold crystallization temperature $\left(\mathrm{T}_{c c}\right)$. The $\mathrm{T}_{c c}$ observed in treated PLA at $130.94{ }^{\circ} \mathrm{C}$ is depressed to $71.72^{\circ} \mathrm{C}$ and to $69.26^{\circ} \mathrm{C}$ with addition of $30 \%$ of TEC and ATBC respectively. The decreasing of $\mathrm{T}_{\mathrm{g}}, \mathrm{T}_{\mathrm{cc}}$ and melting temperature $\left(\mathrm{T}_{\mathrm{m}}\right)$ were

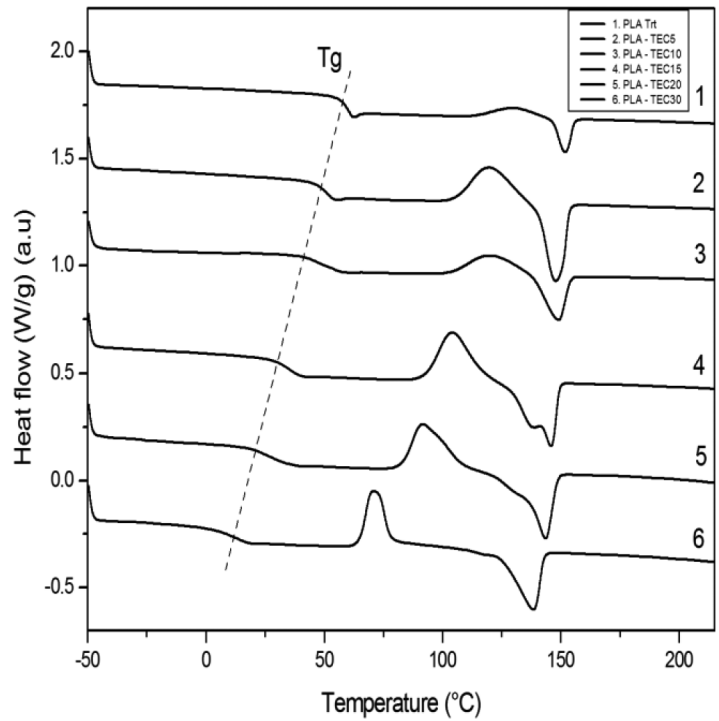

(a)

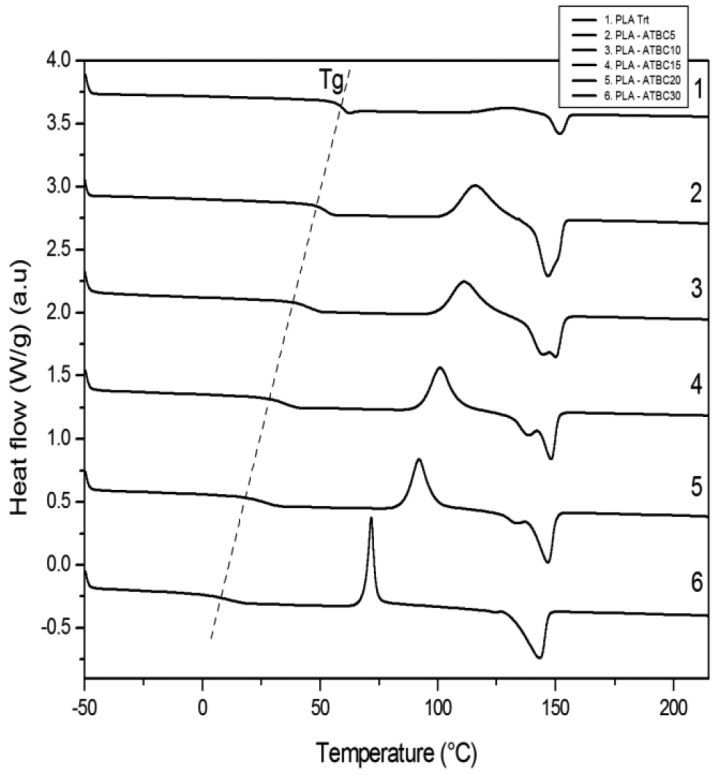

(b)

Figure 1. DSC diagrams of treated PLA and plasticized PLA with: (a) PLA/TEC; (b) PLA/ATBC at various concentrations.

Table 2. Thermal properties and crystallinity of treated and plasticized PLA with TEC and ATBC at various concentrations.

\begin{tabular}{ccccccc}
\hline Formulation & $\mathbf{T}_{\mathbf{g}}\left({ }^{\circ} \mathbf{C}\right)$ & $\Delta \mathbf{H}_{\mathrm{cc}}(\mathbf{J} / \mathbf{g})$ & $\mathbf{T}_{\mathrm{cc}}\left({ }^{\circ} \mathbf{C}\right)$ & $\Delta \mathbf{H}_{\mathrm{m}}(\mathbf{J} / \mathbf{g})$ & $\mathbf{T}_{\mathrm{m}}\left({ }^{\circ} \mathbf{C}\right)$ & $\mathbf{X}_{\mathbf{c}}(\mathbf{\%})$ \\
\hline Trt PLA & 60.42 & 4.986 & 130.94 & 5.240 & 151.90 & 0.27 \\
PLA- TEC5 & 50.48 & 19.15 & 120.27 & 18.46 & 147.89 & 0.78 \\
PLA- TEC10 & 41.20 & 10.62 & 114.77 & 11.46 & 149.04 & 1.00 \\
PLA- TEC15 & 31.21 & 21.35 & 104.39 & 22.48 & 145.90 & 1.42 \\
PLA- TEC20 & 23.56 & 19.38 & 91.73 & 23.07 & 143.55 & 4.95 \\
PLA- TEC30 & 10.29 & 16.63 & 71.12 & 22.22 & 143.27 & 8.58 \\
PLA-ATBC5 & 52.94 & 22.53 & 116.03 & 24.71 & 146.91 & 2.46 \\
PLA-ATBC10 & 44.22 & 21.33 & 108.29 & 24.24 & 150.04 & 3.47 \\
PLA-ATBC15 & 36.67 & 21.09 & 101.10 & 24.73 & 148.14 & 4.60 \\
PLA-ATBC20 & 27.02 & 20,63 & 89.03 & 24.46 & 146.80 & 5.14 \\
PLA-ATBC30 & 12.21 & 13.97 & 69.26 & 19.88 & 138.41 & 9.07 \\
\hline
\end{tabular}

$\mathrm{T}_{\mathrm{g}}$ : glass transition temperature; $\mathrm{T}_{\mathrm{m}}$ : melt temperature; $\mathrm{T}_{\mathrm{cc}}$ : cold crystallization; $\Delta \mathrm{H}_{\mathrm{m}}$ : melting enthalpy; $\Delta \mathrm{H}_{\mathrm{cc}}$ : enthalpy of the cold crystallization; $\mathrm{X}_{\mathrm{c}}$ : crystallinity. 
enhanced with a higher plasticizer content as a result from the enhanced chain mobility ${ }^{[23]}$.

The decrease of $T_{g}, T_{c c}, T_{m}$ and the increase of degree of crystallinity as show in Table 2 was seen to depend on the plasticizer content. The percentage of crystallinity of the plasticized PLA is higher than that the treated PLA. For the plasticized PLA with TEC, greatest crystallinity is observed with addition of $30 \%$ for a value of $8.58 \%$, and a rate of $9.07 \%$ for the plasticized PLA/ATBC. This increase indicates that the crystallization of the PLA becomes easier with the mobility of the chains caused by the citrate ester.

The action of a plasticizer is to increase the free volume and to decrease the polymer chain interactions which induce higher chain mobility at lower temperature, the effect linked to plasticization is most probably superposed with a decrease of the glass transition temperature due to chain mobility. Labrecque et al. ${ }^{[19]}$ studied the effect of plasticizers on the thermal properties of PLA and they have found that all plasticizers were miscible with PLA. The reason for good solubility of PLA in citrate plasticizers is due to the polar interactions between the ester groups of PLA and the plasticizer $^{[20]}$.

\subsection{Dynamic mechanical analysis (DMA)}

Curves displaying storage modulus (E'), loss modulus (E') and loss factor $(\tan \delta)$ were recorded as a function of temperature for the treated PLA and the plasticized PLA are described in Figures 2, 3 and 4 respectively.

Figure $2 \mathrm{a}$ and Figure $2 \mathrm{~b}$ shows the temperature dependence on the storage modulus (E') for the treated and plasticized PLA with TEC and ATBC respectively. There is a decrease in storage modulus values below $\mathrm{T}_{\mathrm{g}}$ as the plasticizer continues to increase the mobility of the polymer chains. The E' curves for the blends display a short plateau comparing with treated PLA. This indicates a decrease in thermal mechanical stability with additional citrate esters in PLA. The addition of plasticizer in PLA is often reported to

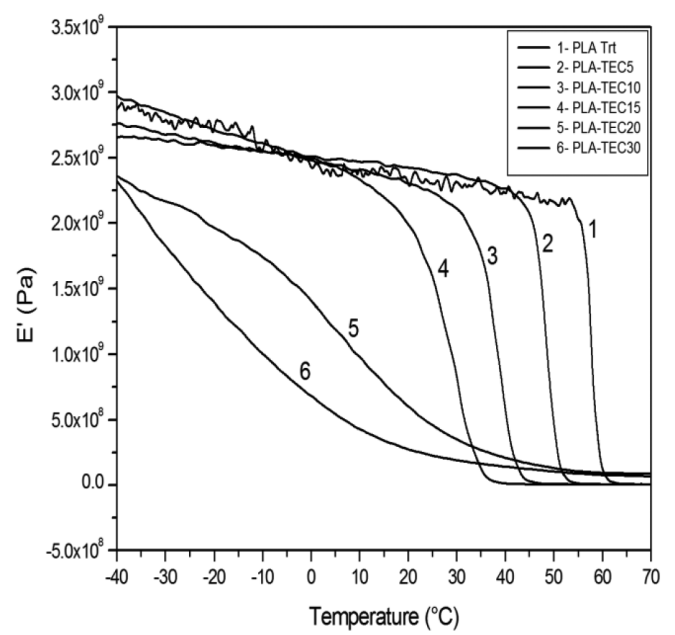

(a) to reduce the stiffness ${ }^{[24]}$. The thermograms show $\alpha$-relaxation (main peaks). It is clearly shown in Figure $3 \mathrm{a}$ and Figure $3 \mathrm{~b}$ that the drop in storage modulus following the $\alpha$-relaxation was found at a lower temperature for the plasticized materials as compared to treated PLA.

The curve loss modulus (E") temperature in Figure 3 provides information about the dispersion and distribution of citrate within PLA phase. Furthermore, a broadening of the width of the peak reflecting the glass transition is due to a plasticizer concentration gradient in all the PLA blends, a widening of the width of the curve increased with the plasticizer content (TEC and ATBC). Regarding the decrease of E' with temperature and the presence of bumps in the $\tan \delta$ curves after the glass transition, they are due to a cold-crystallization process ${ }^{[25]}$. We can also note that the peak area of E", related to the energy required to activate the molecular mobility within the material is different depending on the compositions, the increase of plasticizer content increase the peak area. This suggests that the molecular mobility within the plasticized PLA are easily activated than in the PLA alone. In their work on the phenomena of molecular mobility, David et al. ${ }^{[26]}$, showed that the cooperativity increased with the decrease of disorder and therefore the energy required to activate molecular mobility of a material decreases with the increase of the desorder of one, which is in agreement with the previous result of DSC. The relaxation temperature which can be associated with the glass transition was taken at the maximum of the peak of the damping factor $(\tan \delta)$.

Figure 4 indicates that the $\mathrm{T}_{\mathrm{g}}$ was significant decreased for all the plasticized PLA. The $\mathrm{T}_{\mathrm{g}}^{\mathrm{g}}$ decreases with the increase of plasticizer content in the PLA. For example, at $30 \%$ of TEC and ATBC, the glass transition of PLA decreases from $62.23{ }^{\circ} \mathrm{C}$ to $17.49{ }^{\circ} \mathrm{C}$ and to $26.91{ }^{\circ} \mathrm{C}$, respectively. These values of glass transition temperature $\left(\mathrm{T}_{\mathrm{g}}\right)$ obtained by DMA have the same tendency of the results found by the DSC, where $\mathrm{T}_{\mathrm{g}}$ is decreased by the addition of plasticizer. Table 3 presents the $\mathrm{T}_{\mathrm{g}}$ values for PLA plasticized with

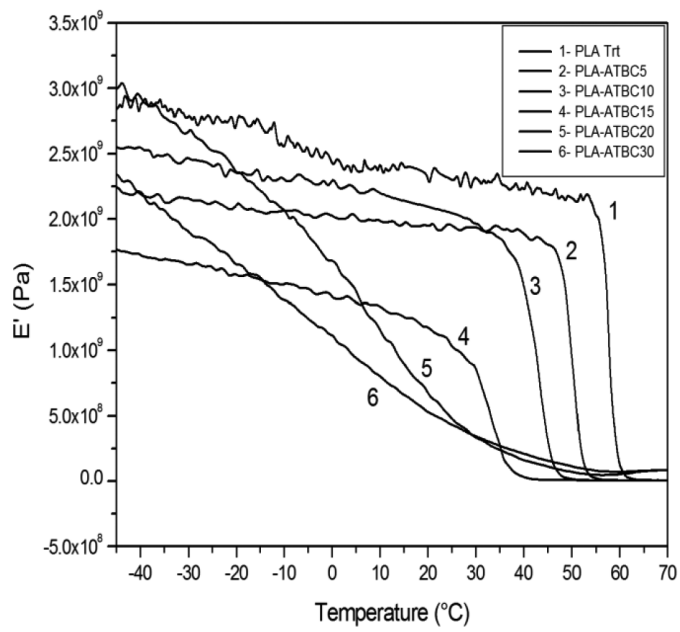

(b)

Figure 2. Variation of storage modulus (E') with temperature of the treated PLA and plasticized PLA with: (a) TEC; (b) ATBC at various concentrations. 


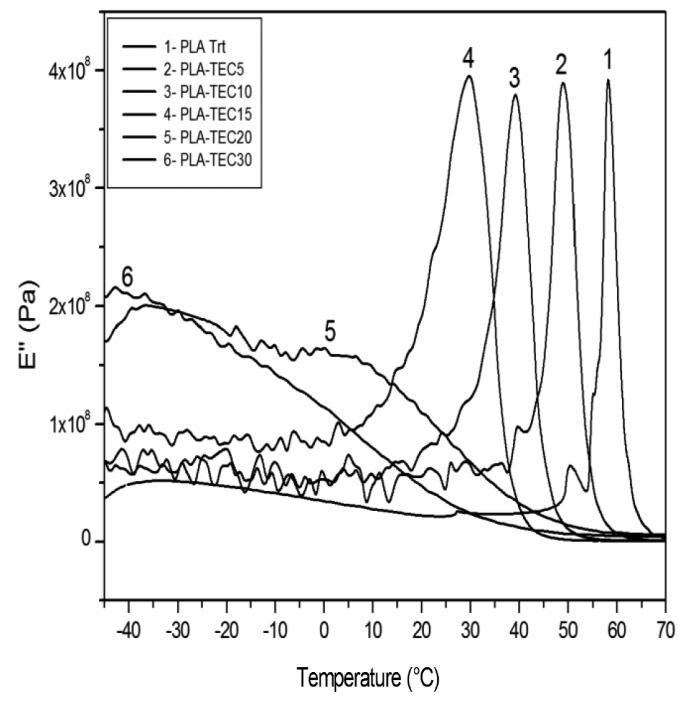

(a)

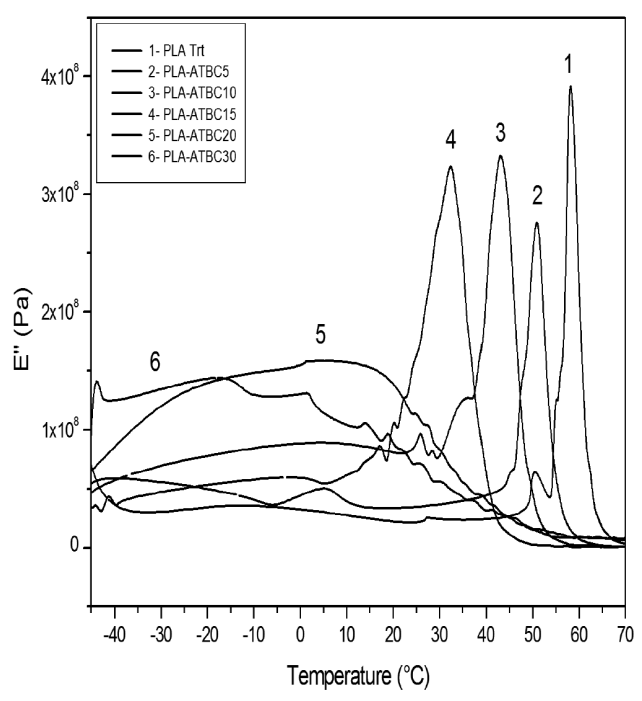

(b)

Figure 3. Variation of loss modulus (E”) with temperature of the treated PLA and plasticized PLA with: (a) TEC; (b) ATBC at various concentrations.

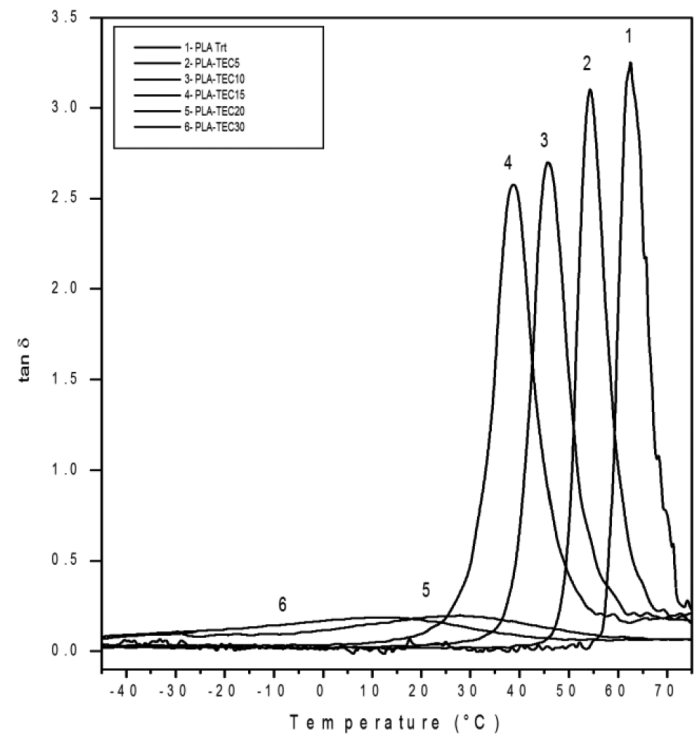

(a)

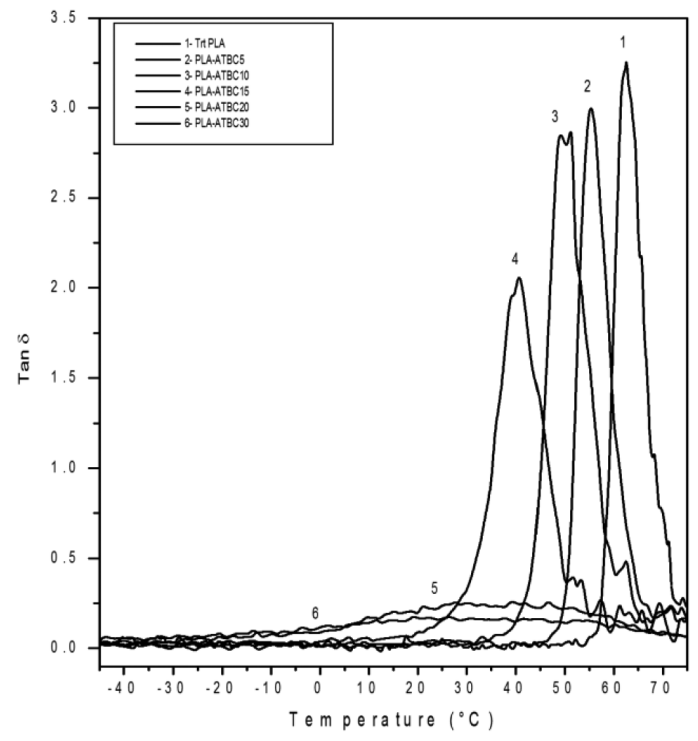

(b)

Figure 4. Variation of loss factor $(\tan \delta$ ) with temperature of the treated PLA and plasticized PLA with: (a) TEC; (b) ATBC at various concentrations.

(TEC or ATBC) obtained by DMA. Furthermore, citrate esters addition also generated broader transition peaks (the full-width half-maximum increased, as indicated in Table 3 and Figure 4). This behavior describes materials with a wide range of relaxation times ${ }^{[27]}$. The presence of citrate changes the microheterogeneity of the systems, i.e., TEC or ATBC chains can cause the formation of a number of microenvironts with different compositions and different interaction densities in the blends. Typical interactions are hydrogen bonding between the hydroxyl groups from PLA and citrate, as well as oxygen, from the citrate esters units, which caused the broadening of the PLA glass transition peak.

\subsection{Melt flow index (MFI)}

The variation of melt flow index (MFI) with the addition of TEC and ATBC was illustrated in Figure 5 respectively. MFI data show that all formulations have higher MFI than of treated PLA ( $4.6 \mathrm{~g}$ per $10 \mathrm{~min})$. The addition of a plasticizer increases the polymer chain mobility which implies a reduction in viscosity and increase of MFI of plasticized PLA $^{[28]}$. When lower quantity of citrate esters is added in 
Table 3. Glass transition temperature and FWHM of the treated PLA and plasticized PLA with TEC and ATBC determined by DMA.

\begin{tabular}{ccc}
\hline Formulation & $\begin{array}{c}\mathbf{T}_{\mathbf{g}}\left({ }^{\circ} \mathbf{C}\right) \\
\text { from } \mathbf{t a n} \boldsymbol{\delta} \text { curve }\end{array}$ & FWHM $\left({ }^{\mathbf{O}} \mathbf{C}\right)^{\mathbf{a}}$ \\
\hline Trt PLA & 62.23 & 6.48 \\
PLA-TEC5 & 54.26 & 6.75 \\
PLA-TEC10 & 45.91 & 7.90 \\
PLA-TEC15 & 38.71 & 8.70 \\
PLA-TEC20 & 31.86 & 18.02 \\
PLA-TEC30 & 17.49 & 20.88 \\
PLA-ATBC5 & 55.24 & 7.02 \\
PLA-ATBC10 & 50.08 & 9.24 \\
PLA-ATBC15 & 40.84 & 10.66 \\
PLA-ATBC20 & 35.69 & 51.18 \\
PLA-ATBC30 & 26.91 & 61.45 \\
\hline
\end{tabular}

a(FWHM): Full-width half-maximum measured from the $\tan \delta$ curve.

PLA, the small citrate molecule can penetrate PLA matrix and then make PLA matrix slip and flow easier. With the addition of citrate increased large amounts of citrate molecule gathered with each other and surrounded the PLA matrix, which can resist slipping and flowing the PLA molecule chain. When the composition of the plasticizer increases, more molecules of the TEC or ATBC surround the PLA, which becomes more fluid and slippery. The melt index is in good correlation with the results of DSC and DMA.

\subsection{Thermogravimetric analysis (TGA)}

Thermogravimetric analysis (TGA) is an effective approach evaluating the thermal stability of polymeric material. Figure $6 \mathrm{a}$ and Figure $6 \mathrm{~b}$ shows the TG and DTG curves of the neat PLA and plasticized PLA with TEC and ATBC respectively.

TGA were carried out on the different formulations reveals that the initial decomposition temperature of plasticized PLA with different concentrations of citrate esters is lower compared to neat PLA. While the kinetics of degradation shows that the plasticized PLA are stable within the range of interest $\left(130^{\circ} \mathrm{C}\right)$. However, the initial decomposition temperature of PLA shifts systematically to lower temperature when citrate esters are added. This shift is globally more important when the amount of plasticizer is higher. For example, a shift from $295{ }^{\circ} \mathrm{C}$ to $141^{\circ} \mathrm{C}$ and to $146^{\circ} \mathrm{C}$ is observed for the initial decomposition temperature of the plasticized PLA with 30\% of TEC and ATBC respectively. The initial decomposition temperature $\left(\mathrm{T}_{\mathrm{i}}\right)$, temperature at $5 \%$ and $50 \%$ weight loss $\left(\mathrm{T}_{5 \%}\right)$ and $\left(\mathrm{T}_{50 \%}\right)$ respectively and temperature of maximum decomposition rate $\left(\mathrm{T}_{\max }\right)$ of treated and plasticized PLA are shown in Table 4. On increasing the concentration of TEC and ATBC, the $\mathrm{T}_{5 \%}$ and $\mathrm{T}_{50 \%}$ are shifted towards lower values. It was also observed the increased of $\mathrm{T}_{\max }$ of PLA with increased of TEC content, further indicating the role of TEC in promoting the thermal resistance of PLA ${ }^{[29]}$. The thermal stability of plasticized PLA with ATBC is greather than those with TEC. The $\mathrm{T}_{\max }$ of the plasticized PLA with ATBC is higher than the treated PLA. The presence of hydroxyl end groups in the PLA oligomer chains was found to be critical for degradation, initiating the chain-scission and decreasing
Table 4. TGA data of treated and plasticized PLA with TEC and ATBC at various concentrations.

\begin{tabular}{ccccc}
\hline Formulation & $\mathbf{T}_{\mathbf{i}}\left({ }^{\circ} \mathbf{C}\right)$ & $\mathbf{T}_{\mathbf{5 \%}}\left({ }^{\circ} \mathbf{C}\right)$ & $\mathbf{T}_{\mathbf{5 0} \%}\left({ }^{\circ} \mathbf{C}\right)$ & $\mathbf{T}_{\max }\left({ }^{\circ} \mathbf{C}\right)$ \\
\hline Trt PLA & 295.30 & 348.94 & 383.43 & 390.00 \\
PLA-TEC5 & 247.51 & 331.56 & 383.26 & 391.43 \\
PLA-TEC10 & 206.11 & 303.54 & 384.52 & 395.52 \\
PLA-TEC15 & 171.81 & 259.43 & 383.05 & 394.98 \\
PLA-TEC20 & 156.53 & 211.04 & 377.72 & 392.25 \\
PLA-TEC30 & 141.08 & 193.40 & 373.98 & 391.32 \\
PLA-ATBC5 & 270.07 & 335.11 & 385.54 & 395.52 \\
PLA-ATBC10 & 214.10 & 313.63 & 383.05 & 393.74 \\
PLA-ATBC15 & 175.37 & 260.57 & 381.30 & 391.08 \\
PLA-ATBC20 & 161.86 & 254.00 & 378.96 & 394.27 \\
PLA-ATBC30 & 146.58 & 214.36 & 373.85 & 390.01 \\
\hline
\end{tabular}

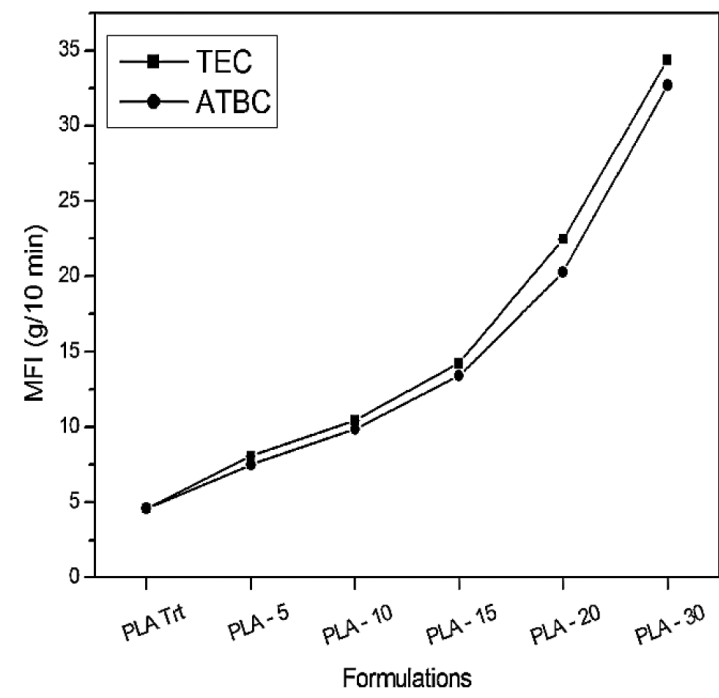

Figure 5. Variation of MFI of treated PLA and plasticized PLA with various concentrations of TEC and ATBC.

the thermal stability ${ }^{[30,31]}$. The range temperature between 284 and $335^{\circ} \mathrm{C}$ corresponds to evaporation of plasticizer components, that's where the boiling point of TEC and ATBC is $127^{\circ} \mathrm{C}$ and $173{ }^{\circ} \mathrm{C}$ respectively, where they appear clearly in DTG of plasticized PLA with $30 \%$ of TEC or ATBC.

\subsection{X-ray diffraction $(X R D)$}

The X-ray diffraction (XRD) is used to observe changes in the crystallinity of the realized formulations. Figure $7 \mathrm{a}$ and Figure $7 \mathrm{~b}$ show the XRD patterns of treated PLA and plasticized PLA with TEC and ATBC respectively.

The PLA has only a strong diffraction at $16.7^{\circ}$ assigned to the crystalline phase $\alpha$, which confirms that the PLA has no polymorphic crystalline transition ${ }^{[32]}$. The PLA alone and various formulations have the same crystal structure ${ }^{[20]}$. The diffraction peaks corresponding to the plasticized PLA are offset slightly with increasing TEC and ATBC content and a greater shift for the composition PLA-TEC or ATBC at $30 \%$ probably total crystallinity. This indicates that the incorporation of the plasticizer accelerates the 


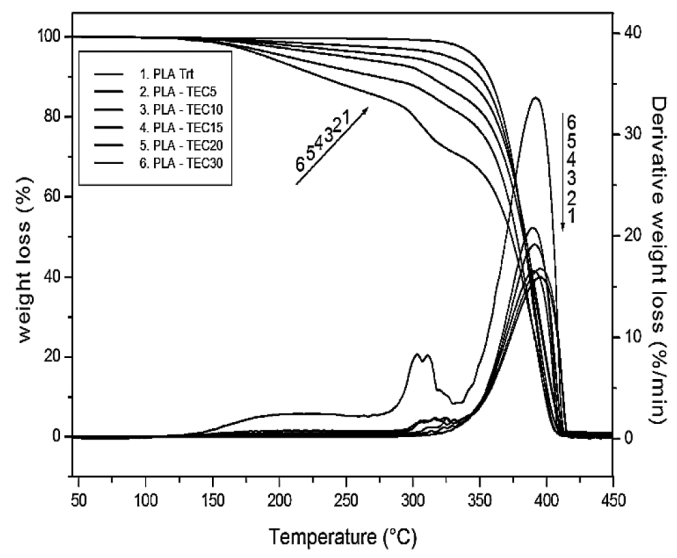

(a)

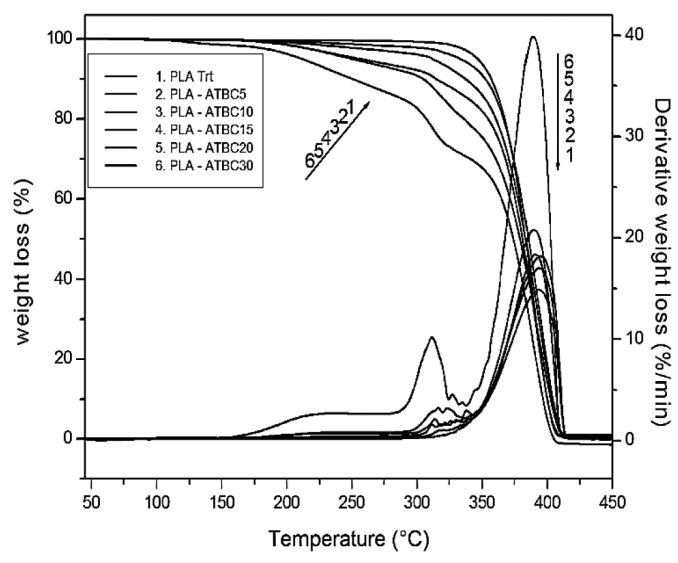

(b)

Figure 6. TGA/DTG thermograms of treated PLA and plasticized PLA with: (a) TEC; (b) ATBC at various concentrations.

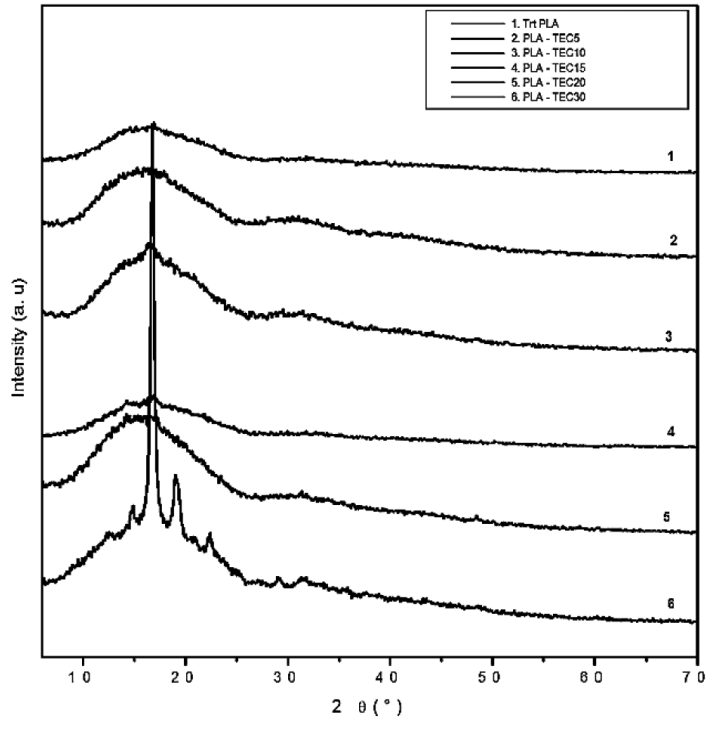

(a)

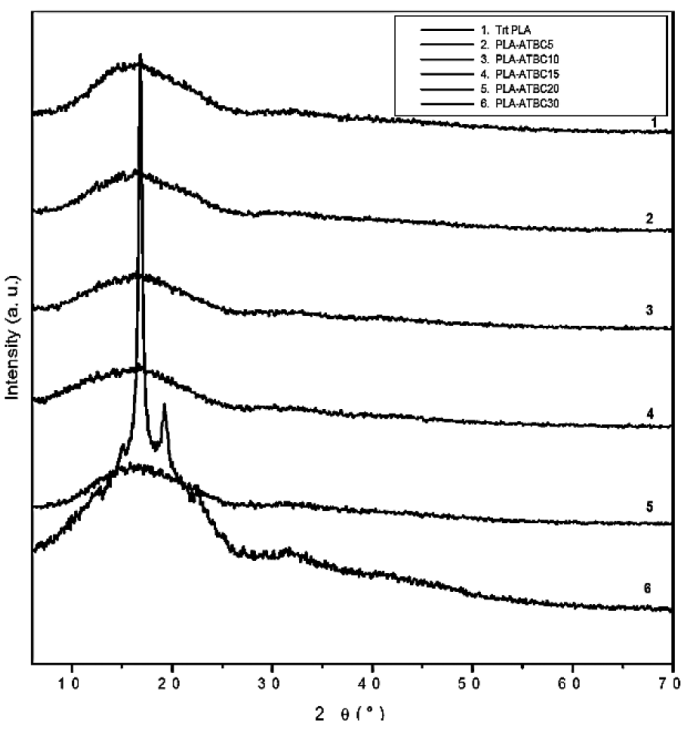

(b)

Figure 7. X-ray diffractograms for treated PLA and plasticized PLA with: (a) TEC; (b) ATBC at various concentrations.

crystallization of PLA, the same result found by DSC. This can be explained by the finding by Miyajima et al. ${ }^{[33]}$, Li et al. ${ }^{[34]}$, that the chain mobility of amorphous PLA could increase the crystallinity due to the production of PLA with lower molecular weight and shorter chain which was more mobile and more susceptible to crystallize than longer ones.

\subsection{UV-Visible spectroscopy}

To further study the effect of these plasticizers on the transparency of the PLA. The UV-visible light transmittance of treated and plasticized PLA with TEC and ATBC were measured as shows in Figure 8a and Figure 8b.

The spectra clearly show that whatever the level of plasticizer, the general appearances of all spectra are identical. All the maximum absorbance range are between about 208-214 nm. Both plasticizers (TEC and ATBC) have no effect on the color change of the films. In the same field, there appear weak staining is due to the effect of film thickness.

\subsection{Plasticizer migration}

The weight loss, assumed as the weight loss of the plasticizer, was calculated as an arithmetic mean of three measured values. The variation of weight loss of treated and plasticized PLA with TEC and ATBC as a function of time at $100^{\circ} \mathrm{C}$ and $135^{\circ} \mathrm{C}$ is shown in Figure $9 \mathrm{a}$ and Figure $9 \mathrm{~b}$. The plasticizer loss increases with time and at $100{ }^{\circ} \mathrm{C}$ is lower than at $135^{\circ} \mathrm{C}$. It's clear that higher temperature favors the plasticizer migration. Citrate esters (TEC and ATBC) migrated out of the PLA at elevated temperature. Plasticizer weight loss was directly proportional to the temperature and plasticizer concentration in PLA. Higher temperatures eased plasticizer migration compared to lower temperatures. The rate of weight loss at $135^{\circ} \mathrm{C}$ is highest at $400 \mathrm{~min}$ for all samples. After $800 \mathrm{~min}$ all citrate esters 


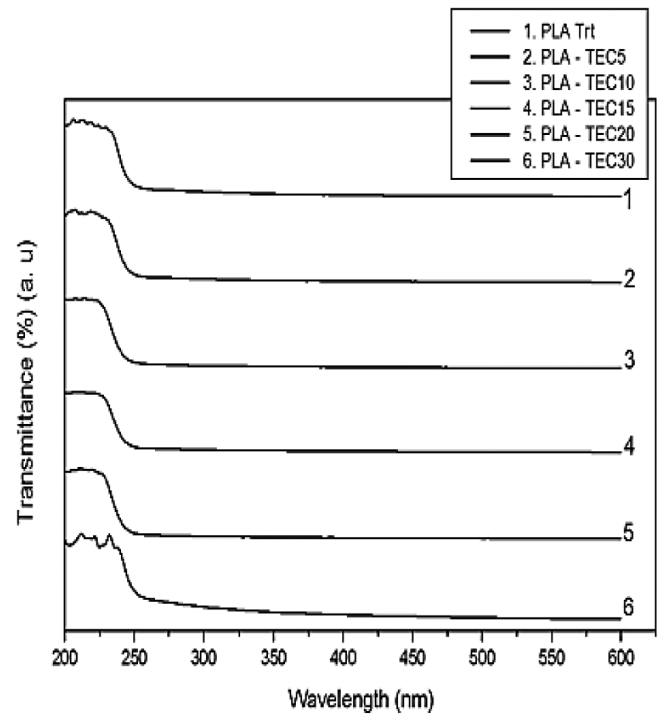

(a)

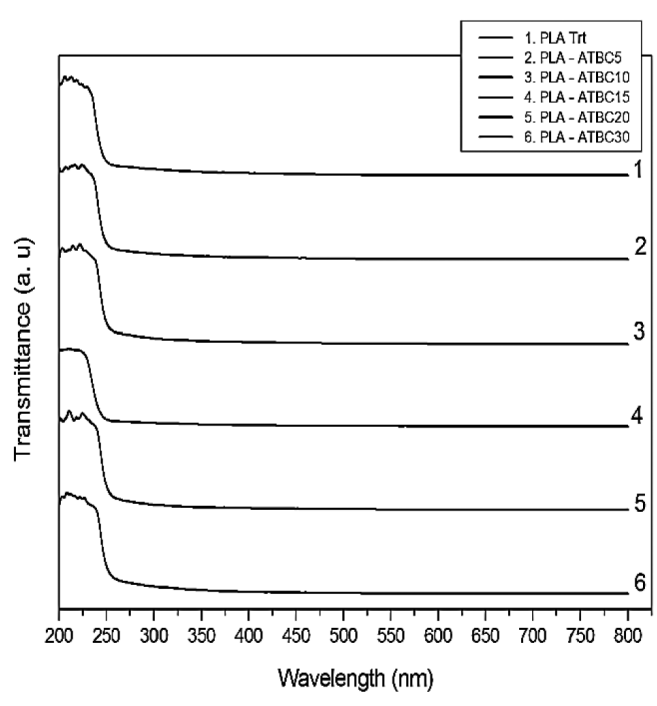

(b)

Figure 8. UV- Visible spectra of treated PLA and plasticized PLA with: (a) TEC; (b) ATBC at various concentrations.
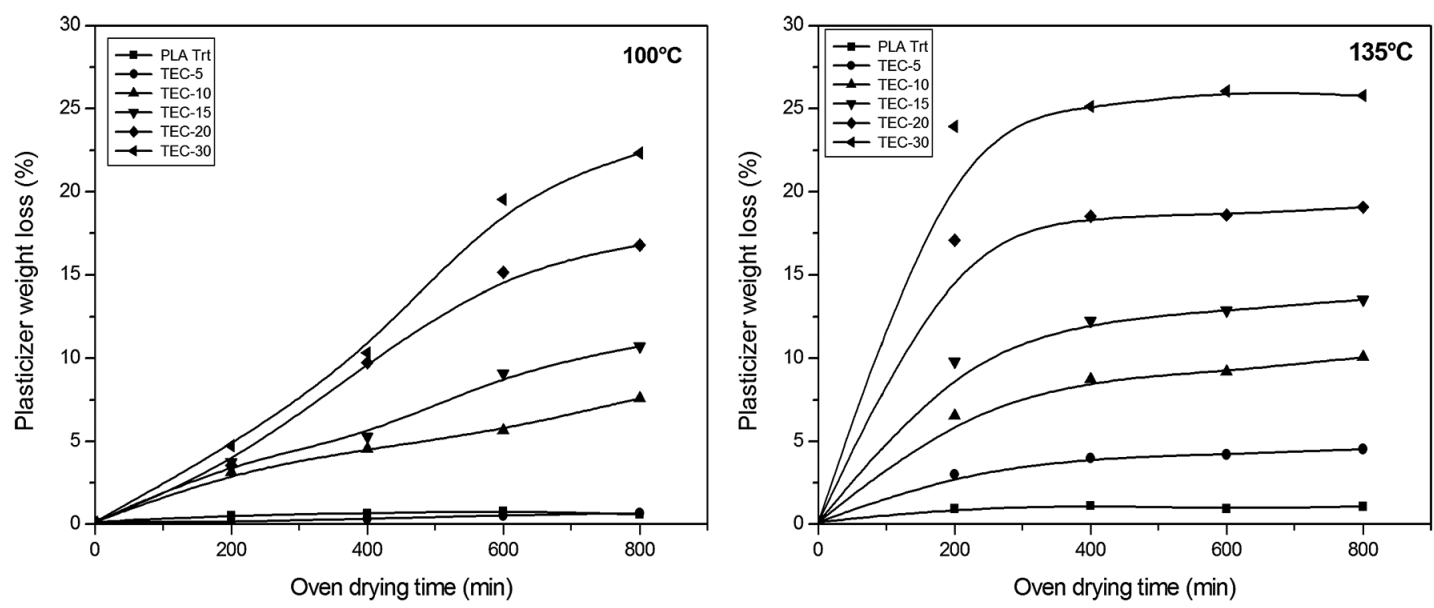

(a)
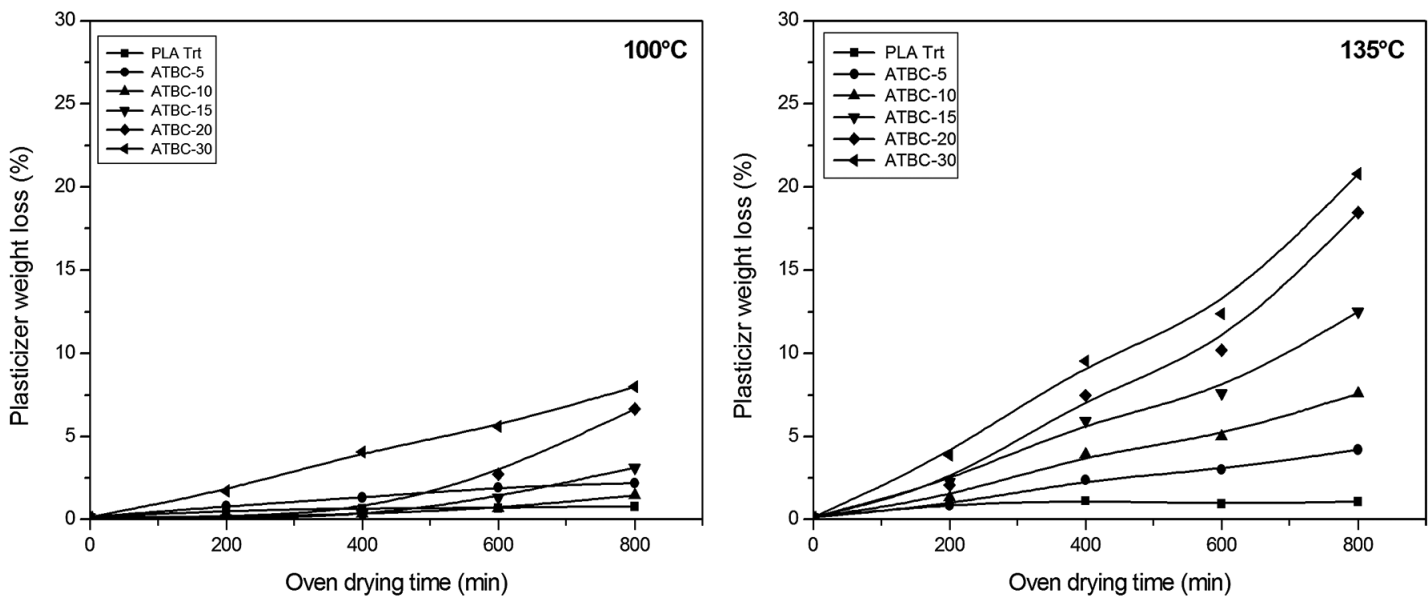

(b)

Figure 9. Weight loss of treated PLA and plasticized PLA with: (a) PLA/TEC; (b) PLA/ATBC at various concentrations after heating at $100{ }^{\circ} \mathrm{C}$ and $135^{\circ} \mathrm{C}$. 
migrate from the simple and all the samples show little color changes at $100{ }^{\circ} \mathrm{C}$ and $135^{\circ} \mathrm{C}$. The color change may be evidence of the increase of PLA crystallinity and / or thermal degradation. In the case of sample PLA plasticized with TEC is transparent and colorless ATBC becomes opaque and it can be concluded that the change in degree of crystallinity is the main reason. After $800 \mathrm{~min}$ at $135^{\circ} \mathrm{C}$ the effect of the migration is more visible and the samples are cracked and broken (especially plasticized PLA). The color change of all samples is also more pronounced. In case of loss of plasticizer is worsened flexibility, ie. The samples become more rigid and easy to break.

\section{Conclusions}

In this study, the characterization of plasticized PLA with TEC and ATBC by using the simple melt blending method was reported. The thermal properties of plasticized PLA shows that TEC and ATBC are effective in lowering the glass transition temperature $\left(\mathrm{T}_{\mathrm{g}}\right)$, the melting temperature $\left(T_{m}\right)$ and the cold crystallization temperature $\left(T_{c c}\right)$ of the PLA. In addition, its crystallinity increases with increasing content of plasticizer. The evaluation of the influence of the type and plasticizer content on the viscoelastic properties of PLA with DMA indicates a decrease in the storage modulus is observed for plasticized PLA, indicating the flexibility and mobility of the amorphous phase of PLA caused by TEC and ATBC. The value of the melt flow index (MFI) was observed for all samples are higher than those of neat PLA. The TGA results indicated that the TEC and ATBC promote a decrease in thermal stability of the PLA. X-ray diffraction shows the appearance of a strong diffraction at $16.7^{\circ}$ assigned to the crystalline phase $\alpha$, which confirms that the PLA has no crystalline polymorph transition. UV-Visible spectroscopy shows that the two plasticizers: ATBC and TEC have no effect on the color change of the films. Thermally induced migration of citrate esters (TEC and ATBC) from plasticizer PLA was investigated. The weight loss plasticizer with heating time and at $100{ }^{\circ} \mathrm{C}$ is lesser than at $135^{\circ} \mathrm{C}$. migration of TEC and ATBC results in cracks and changed color of material., Finally it can be said that the higher molecular weight of citrate exhibited a greater plasticizing effect to the PLA.

\section{References}

1. Al-Mulla, E. A. J., Yunus, W. M. Z. W., Ibrahim, N. A. B., \& Rahman, M. Z. A. (2010). Properties of epoxidized palm oil plasticized polytlactic acid. Journal of Materials Science, 45(7), 1942-1946. http://dx.doi.org/10.1007/s10853-009-4185-1.

2. Phetwarotai, W., Potiyaraj, P., \& Aht-Ong, D. (2012). Characteristics of biodegradable polylactide/gelatinized starch films: Effects of starch, plasticizer, and compatibilizer. Journal of Applied Polymer Science, 126(1), 162-172. http://dx.doi. org/10.1002/app.36736.

3. Li, H., \& Huneault, M. A. (2007). Effect of nucleation and plasticization on the crystallization of poly (lactic acid). Polymer, 48(23), 6855-6866. http://dx.doi.org/10.1016/j. polymer.2007.09.020

4. Yu, L., Dean, K., \& Li, L. (2006). Polymer blends and composites from renewable resources. Progress in Polymer Science, 31(6), 576-602. http://dx.doi.org/10.1016/j.progpolymsci.2006.03.002.
5. Huneault, M. A., \& Li, H. (2007). Morphology and properties of compatibilized polylactide/thermoplastic starch blends. Polymer, 48(1), 270-280. http://dx.doi.org/10.1016/j.polymer.2006.11.023.

6. Pillin, I., Montrelay, N., \& Grohens, Y. (2006). Thermo-mechanical characterization of plasticized PLA: Is the miscibility the only significant factor. Polymer, 47(13), 4676-4682. http://dx.doi. org/10.1016/j.polymer.2006.04.013.

7. Kulinski, Z., \& Piorkowska, E. (2005). Crystallization, structure and properties of plasticized poly (l-lactide). Polymer, 46(23), 10290-10300. http://dx.doi.org/10.1016/j.polymer.2005.07.101.

8. Hu, Y., Rogunova, M., Topolkaraev, V., Hiltner, A., \& Baer, E. (2003). Aging of poly (lactide)/poly (ethylene glycol) blends. Part 1. Poly (lactide) with low stereoregularity. Polymer, 44(19), 5701-5710. http://dx.doi.org/10.1016/S0032-3861(03)00614-1.

9. Hu, Y., Hu, Y. S., Topolkaraev, V., Hiltner, A., \& Baer, E. (2003). Aging of poly (lactide)/poly (ethylene glycol) blends. Part 2. Poly (lactide) with high stereoregularity. Polymer, 44(19), 5711-5720. http://dx.doi.org/10.1016/S0032-3861(03)00615-3.

10. Younes, H., \& Cohn, D. (1988). Phase separation in poly (ethylene glycol)/poly (lactic acid) blends. European Polymer Journal, 24(8), 765-773. http://dx.doi.org/10.1016/00143057(88)90013-4.

11. Xiao, H., Liu, F., Jiang, T., \& Yeh, J. T. (2010). Kinetics and crystal structure of isothermal crystallization of poly (lactic acid) plasticized with triphenyl phosphate. Journal of Applied Polymer Science, 117(5), 2980-2992. http://dx.doi.org/10.1002/ app.32225.

12. Burgos, N., Martino, V. P., \& Jiménez, A. (2013). Characterization and ageing study of poly (lactic acid) films plasticized with oligomeric lactic acid. Polymer Degradation \& Stability, 98(2), 651-658. http://dx.doi.org/10.1016/j.polymdegradstab.2012.11.009.

13. Liu, H., \& Zhang, J. (2011). Research progress in toughening modification of poly (lactic acid). Journal of Polymer Science. Part B, Polymer Physics, 49(15), 1051-1083. http://dx.doi. org/10.1002/polb.22283.

14. Harte, I., Birkinshaw, C., Jones, E., Kennedy, J., \& DeBarra, E. (2013). The effect of citrate ester plasticizers on the thermal and mechanical properties of poly (DL-lactide). Journal of Applied Polymer Science, 127(3), 1997-2003. http://dx.doi. org/10.1002/app.37600.

15. Martino, V. P., Ruseckaite, R. A., \& Jiménez, A. (2006). Thermal and mechanical characterization of plasticized poly (1-lactide-co-d, 1-lactide) films for food packaging. Journal of Thermal Analysis and Calorimetry, 86(3), 707-712. http:// dx.doi.org/10.1007/s10973-006-7897-3.

16. Ljungberg, N., \& Wesslén, B. (2003). Tributyl citrate oligomers as plasticizers for poly (lactic acid): thermo-mechanical film properties and aging. Polymer, 44(25), 7679-7688. http:// dx.doi.org/10.1016/j.polymer.2003.09.055.

17. Urayama, H., Moon, S., \& Kimura, Y. (2003). Microstructure and thermal properties of polylactides with different L- and D-Unit Sequences: importance of the helical nature of the L-sequenced segments. Macromolecular Materials and Engineering, 288(2), 137-143. http://dx.doi.org/10.1002/ mame.200390006.

18. Gutierrez-Villarreal, M. H., \& Rodrìguez-Velazquez, J. (2007) The effect of citrate esters as plasticizers on the thermal and mechanical properties of poly (methyl methacrylate). Journal of Applied Polymer Science, 105(4), 2370-2375. http://dx.doi. org/10.1002/app.25482.

19. Labrecque, L. V., Kumar, R. A., Davé, V., Gross, R. A., \& McCarthy, S. P. (1997). Citrate esters as plasticizers for poly (lactic acid). Journal of Applied Polymer Science, 66(8), 1507-1513. http://dx.doi.org/10.1002/(SICI)10974628(19971121)66:8<1507::AID-APP11>3.0.CO;2-0. 
20. Ren, Z., Dong, L., \& Yang, Y. (2006). Dynamic mechanical and thermal properties of plasticized poly (lactic acid). Journal of Applied Polymer Science, 101(3), 1583-1590. http://dx.doi. org/10.1002/app.23549.

21. Perinović, S., Andričić, B., \& Čagalj, M. (2010). Migration and leaching of plasticizer from plasticized poly (L-lactide)/olive stone flour composites. In Proceedings of the 14th European Conference on Composite Materials (pp. 1-10). Budapest.

22. Oyama, H. T. (2009). Super-tough poly(lactic acid) materials: reactive blending with ethylene copolymer. Polymer, 50(3), 747-751. http://dx.doi.org/10.1016/j.polymer.2008.12.025.

23. Lemmouchi, Y., Murariu, M., Santos, A. M. D., Amass, A. J., Schacht, E., \& Dubois, P. (2009). Plasticization of poly (lactide) with blends of tributyl citrate and low molecular weight poly (d, l-lactide)-b-poly (ethylene glycol) copolymers. European Polymer Journal, 45(10), 2839-2848. http://dx.doi. org/10.1016/j.eurpolymj.2009.07.006.

24. Courgneau, C., Domenek, S., Guinault, A., Avérous, L., \& Ducruet, V. (2011). Analysis of the structure-properties relationships of different multiphase systems based on plasticized poly (lactic acid). Journal of Polymers and the Environment, 19(2), 362371. http://dx.doi.org/10.1007/s10924-011-0285-5.

25. Hassouna, F., Raquez, J.-M., Addiego, F., Dubois, P., Toniazzo, V., \& Ruch, D. (2011). New approach on the development of plasticized polylactide (PLA): grafting of poly (ethylene glycol) (PEG) via reactive extrusion. European Polymer Journal, 47(11), 2134-2144. http://dx.doi.org/10.1016/j. eurpolymj.2011.08.001.

26. David, L., Quinson, R., Gauthier, C., \& Perez, J. (1997). The role of anelasticity in high stress mechanical response and physical properties of glassy polymers. Polymer Engineering and Science, 37(10), 1633-1640. http://dx.doi.org/10.1002/ pen.11811.

27. Ferrarezi, M. M. F., Taipina, M. O. L., Silva, C. E., \& Gonçalves, M. C. (2013). Poly (ethylene glycol) as a compatibilizer for poly (lactic acid)/thermoplastic starch blends. Journal of
Polymers and the Environment, 21(1), 151-159. http://dx.doi. org/10.1007/s10924-012-0480-Z.

28. Sungsanit, K., Kao, N., Bhattacharya, S. N., \& Pivsaart, S. (2010). Physical and rheological properties of plasticized linear and branched PLA. Rheology Journal, 22(3), 187-195.

29. Burgos, N., Tolaguera, D., Fiori, S., \& Jiménez, A. (2014). Synthesis and characterization of lactic acid oligomers: evaluation of performance as poly (Lactic Acid) plasticizers. Journal of Polymers and the Environment, 22(2), 227-235. http://dx.doi.org/10.1007/s10924-013-0628-5.

30. Fan, Y., Nishida, H., Shirai, Y., \& Endo, T. (2004). Thermal stability of poly (1-lactide): influence of end protection by acetyl group. Polymer Degradation \& Stability, 84(1), 143-149. http://dx.doi.org/10.1016/j.polymdegradstab.2003.10.004.

31. Xu, L., Crawford, K., \& Gorman, C. B. (2011). Effects of temperature and $\mathrm{pH}$ on the degradation of poly (lactic acid) brushes. Macromolecule, 44(12), 4777-4782. http://dx.doi. org/10.1021/ma2000948.

32. Kalb, B., \& Pennings, A. J. (1980). General crystallization behaviour of poly (-lactic acid). Polymer, 21(6), 607-612. http://dx.doi.org/10.1016/0032-3861(80)90315-8.

33. Miyajima, M., Koshika, A., Okada, J., Ikeda, M., \& Nishimura, K. (1997). Effect of polymer crystallinity on papaverine release from poly (1-lactic acid) matrix. Journal of Controlled Release, 49(2-3), 207-215. http://dx.doi.org/10.1016/S01683659(97)00081-3.

34. Li, C., Cheng, L., Zhang, Y., Guo, S., \& Wu, W. (2010). Effects of implant diameter, drug loading and end-capping on praziquantel release from PCL implants. International Journal of Pharmaceutics, 386(1-2), 23-29. http://dx.doi.org/10.1016/j. ijpharm.2009.10.046. PMid:19895876.

Received: Nov. 30, 2014

Revised: May 12, 2015

Accepted: Aug. 10, 2015 